DE83 001042

\title{
NUCLEAR MATERIALS INVENTORY PLAN
}

March 1982

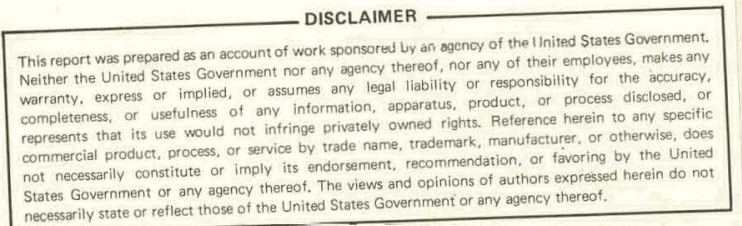

R. W. Doerr

D. H. Nichols

Prepared for the United States

Department of Energy under

Contract DE-ACO6-77RL01030

Rockwell International

Rockwe 11 Hanford Operations

Energy System Group

Richland, WA 99352

UNCLASSIFIED 


\section{DISCLAIMER}

This report was prepared as an account of work sponsored by an agency of the United States Government. Neither the United States Government nor any agency Thereof, nor any of their employees, makes any warranty, express or implied, or assumes any legal liability or responsibility for the accuracy, completeness, or usefulness of any information, apparatus, product, or process disclosed, or represents that its use would not infringe privately owned rights. Reference herein to any specific commercial product, process, or service by trade name, trademark, manufacturer, or otherwise does not necessarily constitute or imply its endorsement, recommendation, or favoring by the United States Government or any agency thereof. The views and opinions of authors expressed herein do not necessarily state or reflect those of the United States Government or any agency thereof. 


\section{DISCLAIMER}

Portions of this document may be illegible in electronic image products. Images are produced from the best available original document. 
TABLE OF CONTENTS

1. ABSTRACT 3

2. GENERAL 4

3. INVENTORY SYSTEM

3.1 CATEGORIZATION OF THE MBA 5

3.2 DETERMINATION OF SAMPLING PARAMETERS $\cdots \quad . \quad \cdots$

3.3 INVENTORY VERIFICATION LISTING 6

3.4 VALIDATION 8

3.5 RECONCILIATION 10

3.6 RESOLUTION OF DISCREPANCIES 11

4. RESPONSIBILITIES 12

4.1 NUCLEAR MATERIALS ACCOUNTING 12

4.2 PRINCIPAL CUSTODIANS 12

4.3 PRODUCTION OPERATIONS 12

4.4 ANALYTICAL LABORATORIES 12

4.5 NUCLEAR MATERIALS MEASUREMENTS 12

4.6 NUCLEAR MATERIALS ADMINISTRATION 12

5. USE OF FORMS 13

5.1 INVENTORY ACTIVITIES REPORT 13

5.2 INVENTORY DISCREPANCY SUMMARY 13

5.3 INVENTORY HOLD TAG 13

6. SUMMARY -.. . . 14

$\begin{array}{ll}\text { APPENDIX A } & 15\end{array}$

APPENDIX B 16

$\begin{array}{ll}\text { ARPENDIX } C & 17\end{array}$ 


\section{ABSTRACT}

In any processing; manufacturing, or active storage facility it is impractical to assume that any physical security system can prevent the diversion of Special Nuclear Material (SNM). It is, therefore, the responsibility of any DOE Contractor, Licensee, or other holder of SNM to provide assurance that loss or diversion of a significant quantity of SNM is detectable. This ability to detect must be accomplishable within a reasonable time interval and can be accomplished only by taking physical inventories. The information gained and decisions resulting from these inventories can be no better than the SNM accounting system and the quality of measurements performed for each receipt, removal and inventory.

Inventories interrupt processing or production operations, increase personnel exposures, and can add significantly to the cost of any operation. Therefore, realistic goals for the inventory must be defined and the relationship of the inherent parameters used in its validation be determined.

The purpose of this document is to provide a statement of goals and a plan of action to achieve them. 


\section{GENERAL}

The inventory at Rockwell Hanford Operations (Rockwell) includes plutonium dioxide, plutonium metal, plutonium nitrate, assorted plutonium bearing scrap, uranyl nitrate solution, oxides of uranium and lesser amounts of other accountable nuclear material.

This inventory of nuclear materials is contained within a system of material balance areas (MBA's), which have physical and/or administrative boundries whereby the amount of material entering or leaving the MBA is a measured quantity. It is at this MBA level that effective physical inventories are taken and evaluated.

Physical inventories will be conducted by validation of all or a statistically signficant sample (as defined in Section 3.3) of each MBA. This validation will be accomplished by attribute testing of the sample and by variable testing on a randomly selected subset of this sample.

The value of $\beta$ (to be defined later) will determine whether a sampling or all items are used for the validation.

Table 2, Appendix A provides a $B$ for each MBA. A listed value of N/A indicates that all items are used for the physical inventory.

Table 2 also provides information on inventory frequency. The four inventory periods are:

- Daily - An administrative determination that no gross irregularities appear to exist. This may include alarm checks, walk-throughs, container counts, empty pedestal checks or combinations thereof.

- Bimonthly - Category I SNM will be inventoried every two months based on a sampling plan or in total. Processing areas will be inventoried during normal shutdown conditions but not less frequently than annually.

- Semiannual - Category II SNM will be inventoried every. six months based on a sampling plan or in total.

- Annual - Category III and Category IV nuclear material will be inventoried in total at least once every twelve months. 


\section{INVENTORY SYSTEM}

The taking of the physical inventory is divided into five phases:

- Categorization of the MBA

- Determination of sampling parameters

- Inventory Validation. Listing.

- Validation

- Reconciliation

\subsection{Categorization of the MBA}

DOE Order 5630.2, "Control and Accountability of Nuclear Materials, Basic Principles", provides the guidance to determine the category for each MBA. Prior to each inventory period an assessment of quantity and type of material for each MBA will determine its category for inventory frequency requirements. The nature of the MBA in conjunction with its category will determine inventory frequency. Table II, Appendix $A$ is a listing of present category and inventory frequency for each MBA.

\subsection{Determination of Sampling Parameters}

Sampling parameters are to be applied to MBA's having a large number of individual items or inactive process areas where previously measured holdup in equipment lends itself to discrete identification.

The two parameters that determine the statistically significant sample are:

- Target Quantity (T.Q.) - A quantity of SNM which defines an unacceptable level of performance.

- Risk ( $B$ ) - Defined as the probability that unacceptable performance will not be detected.

Both T.Q. and $\beta$ are administratively controlled values. Accessability and physical protection are determining factors for $B$ which has values ranging from 0.2 to 0.5 . Material attractiveness and available quantities are evaluated to determine a T.Q.

Figures 1 and 2, Appendix $B$ are provided as visual aids for the effect of these parameters on sample size. 


\subsection{Inventory Verification List}

Nuclear Materials Control Accounting shall prepare a listing for each MBA to be inventoried. The listing (s), where applicable, shall include:

- Location

- Element weight

- Measurement method

- Gross weight

- Sear number (s)

- Item identification

- Material form

- Container type

- Calculated wattage

- Label element weight

A summary page for the MBA will also be generated including:

- Items for variable testing.

- Calculated B

- Known discrepancies

The criteria for selection of items for attribute testing is:

Each MBA will be divided into cells. Where a cell is defined as a continuous segment of SNM content per item. (e.g. 401 to 600 grams or 601 to 900 grams)

- The number of items to be randomly selected from each cell - is calculated by:

$$
N_{i}=\left[\left(N_{i}-\frac{D_{i}-1}{2}\right)\left(1-B_{i} 1 / D_{i}\right)\right]+1
$$

Where: $\quad D_{j}=(T . Q).\left(N_{j}\right) /(T)$

$N_{j}=$ Number of items in cell

$T=$ grams SNM in MBA for element inventoried

$\beta_{j}=(B)^{A}$

$A=\operatorname{SNM}$ (grams) in cell/SNM (grams) in MBA

$n_{i}=$ The number of items to be sampled from Cell $i$. (Expressed as a truncated integer.). 
The specific items to be validated will be selected by a random number selection method.

(*) This equation is a suitable approximation to the hypergeometric distribution.

Selection of items for variable testing is accomplished by modifying the previous equation to:

$$
n_{i}=N_{i}\left(1-\beta_{i} \gamma / D_{i}\right)+0.5
$$

The elements of the equation are defined the same and $\gamma$ represents the precision of the measurement method.

This method of selection optimizes the detection of possible diversion by either gross substitution or partial removal.

The specific items to be tested will be identified by a random number selection method and will be a subset of the attribute sample. 


\subsection{Validation}

The validation: procedure is divided into two phases: attribute and variable testing.

3.4.1. Attribute testing is used for making decisions regarding the acceptability of inventory, based on certain characteristics of the item. The item is classified as acceptable or defective (not acceptable), depending on whether or not the particular characteristic of the item (e.g. location, identification, weight, radiation, etc.) are considered to be satisfactory. Testing on an attribute basis is designed to detect:

- honest mistakes, in the situation where no time diversion has occurred.

$\because$ missing or changed items, where the records or container have been altered to mask diversion.

A11. known discrepancies, between liabel information and the inventory record are noted on the inventory listing and do not constitute a defect.

The procedure for attribute testing is:

- Locate item

- Inspect container and TID (if applied) for integrity

- Verify label information

Refer to Section 3.6 for resolution of defects

3.4.2 Variable testing is used to develop quantitative information regarding the validity of stated quantities. The measurement of a specific property such as:

- Heat output

- Neutron emission

- Specific gamma activity

- Weight

- Chemical reactivity

- Etc.

To provide the capability for using nondestructive or chemical assay methods to detect diversion. 
Table 1, Appendix $B$ contains limits for various measurements and is to be used as a general guide to evaluate the reasonableness of stated quantities.

The data received from measurements will be reviewed on an item by item basis to detect gross discrepancies and collectively to detect "skimming".

Refer to Section 3.6 for resolution of defects. 


\subsection{Reconciliation}

Reconciliation is the comparison of the actual physical inventory findings to the current book values for that MBA, and the adjustment (if necessary) of book values.

Where a statistical sampling plan is used, reconciliation is a comparison of the physical inventory findings to the current book values for that sample.

If no major discrepancies are found, reconciliation is to be completed within five working days from receipt of measured values. 


\subsection{Resolution of Defects}

3.6.1 If a container appears to have been opened or substituted as evidenced either by container or TID condition, the inventory will be discontinued. Immediate notification of appropriate authorities is required and a complete MBA inventory and investigation is conducted.

3.6.2 If a statistical difference between measured and book yalue for an item or group of items is noted, immediate notification of appropriate authorities is required and an investigation conducted.

3.6.3 Minor discrepancies in label information will be noted on the inventory listing and resolved upon completion of the inventory.

3.6.4 Discrepancies not covered above, such as an item not in its assigned storage location, will be investigated immediately after the inventory. Appropriate notifications and actions will follow the findings of the preliminary investigation.

3.6.5 The MBA will remain closed to all transfer of material except those associated directly with the investigation. 
- 12 RHO-MA-1106, Rev. 1

\section{RESPONSIBILITIES}

4.1 Nuclear Materials Accounting

- Provides inventory listings

- Assists custodians in reconciliation

4.2 Principal Custodians

- Provides detailed inventory procedures

- Conducts the physical inventory

- Performs reconciliation

- Resolves differences in attribute data

- Reports significant discrepancies to the Manager, Nuclear Materials Control

- Coordinates all aspects of the program with plant management and implements recommendations for corrective action.

- Provides access to, and control within, the MBA

- Plans, schedules and maintains records of inventory activities

4.3 Production Operations

- Provide operational support for the inventory activities, including weight checks, nondestruction assay, sampling and labeling

4.4 Analytical Laboratories

- Maintain auditable records generated during equipment

- calibration and nuclear material measurements

- Provide analytical support services

4.5 Nuclear Material Measurements

- Assists custodian in reconciliation

4.6 Nuclear Material Administration

- Audits compliance with inventory procedures 


\section{USE OF FORMS}

\subsection{Inventory Activities Report}

The "Inventory Activities Report" form identifies the items verified and provides a record of all verification efforts afforded each item. Lack of substantiation or other questionable status is noted in the space provided at the bottom of the form. The completed form is signed by the custodian and includes the names of all personnel involved.

\subsection{Inventory Discrepancy Summary}

This form is used to provide a detailed record of the observed discrepancy and the action taken to resolve questionable status. The completed form is signed by the custodian and includes the names of all personnel involved in the investigation.

\subsection{Inventory Hold Tag}

The "Inventory Hold Tag" is used to prevent issuance of, or tampering with, the item being held. Each item must be tagged and removed from production channels.

Inventory and Operations personnel shall implement the necessary activities to effect early resolution of the problem. The lower portion of the tag shall contain the detailed disposition instructions and shall be signed by the custodian and approved by Nuclear Materials Control management.

An example of each of the above forms is provided in Appendix $C$. 


\section{SUMMARY}

The inventory, as planned and conducted, provides, with an acceptable degree of uncertainty, that loss or diversion of nuclear material has not occurred. It follows the graded safeguard concept of providing a degree of protection for materials based on their attractiveness to diversion and does so in a timely manner. 
APPENDIX A 
101

102

103

104

105

106

107

201

202

203

204

205

206

301

302

303

304

305
Facility Services - Z Plant.

Plutoniun Reclamation - 2 Plant

Plutonium Conversion - 2 Plant

Product Mandling and Operations

Product Handling and'Operations I tem Control

PWR Core II - BIdg 221-T

D\&D - Bldg 233-S

Uranyl Nitrate Storage - Purex $\mathrm{P}$ Tanks

N/A

III

Exempt

IV

Tank Farms Operations - 2COE \& 200W

Process Control Laboratory - Z Plant

Process Control Laboratory - Purex

Radio Chemical Standards Laboratory. 222-S

Radio Cinemical Standards Laboratory Z Plant

Process Control Laboratory - 222-5
III

IB

J. W. Patterson

J. W. Patterson

J. W. Patterson

J. W. Patterson

J. W. Patterson

Exempt

J. W. Patterson

J. W. Patterson

B. F. Campbell

B. F. Campbell

B. F. Campbel1

B. F. Campbe11

B. F. Campbe1!

B. F. Weaver

IA

C. P. Sutter

III

III

IA

III
C. P. Sutter

C. P. Sutter

C. P. Sutter

C. P. Sutter
H. V. Colton

R. R. Lehrschall

T. J. Keefe

M. D. Swett

F. F. Walters

M. K. Bayless

J. B. Shannon

J. D. McIntosh

C. A. Petersen None (Future MBA)

G. E. Milliward

C. A. Petersen

R. C. AdamIs

B. R. FitzPatrick

R. Á. Buchanan

D. J. McCain

D. J. McCain

R. Maffeo 


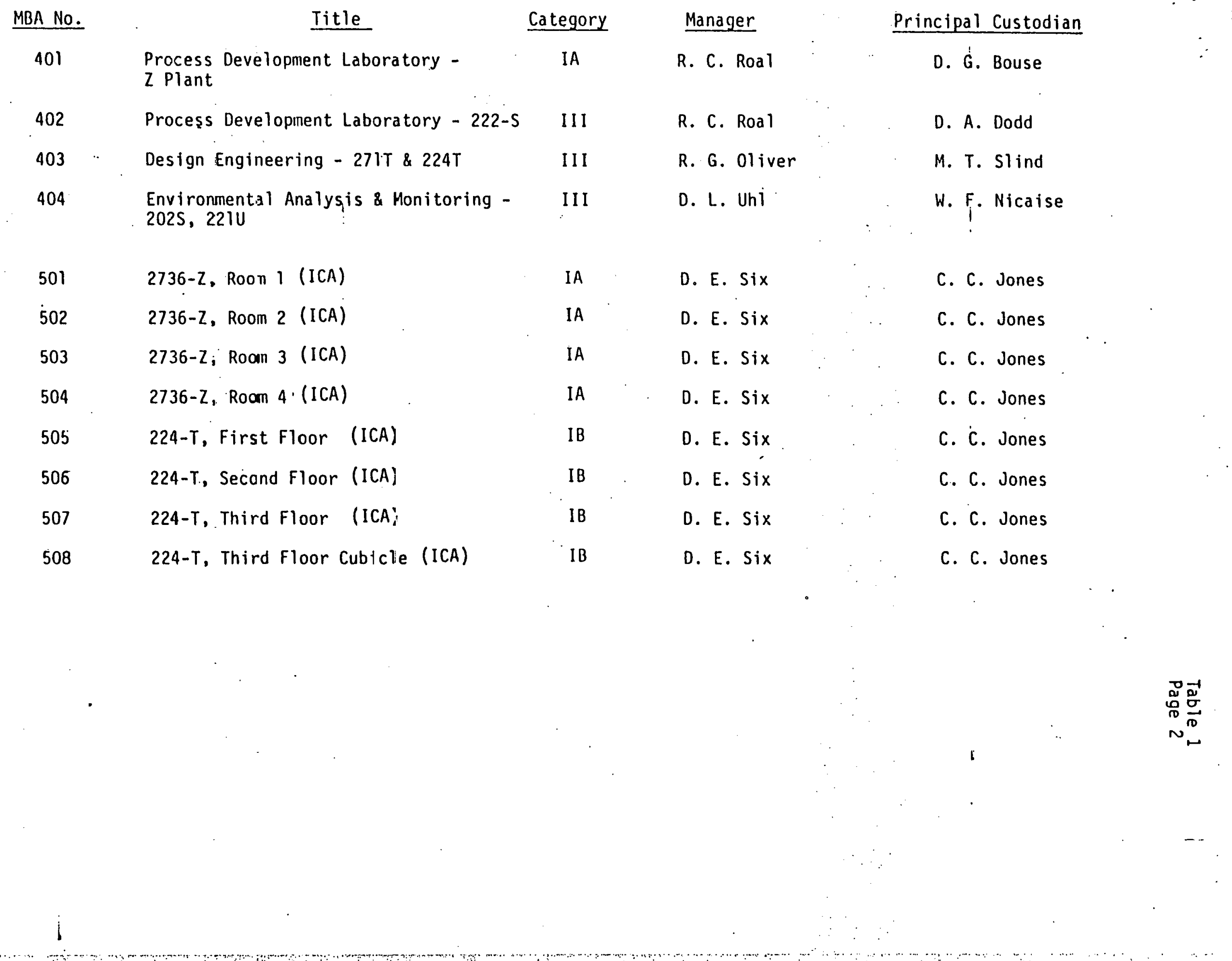




\section{APPENDIX A, TABLE 2 - Classified \\ See RHO-SS-PL-6}



TABLE 1

Description

Storage Weight

$\mathrm{Pu}$ Concentration

Pu Concentration

Density

Pu Metal/Oxide

Pu Metal/Oxide

Pu Nitrate

Scrap Metal

Scrap Oxide

Incinerator Ash

Incinerator Ash

- Slag and Crucible

Slag and Crucible

$\mathrm{Pu}$ in Polystyrene

$\mathrm{Pu}$ in Graphite

$\mathrm{Pu}$ in Waste Cartons

Miscellaneous Offsite Scrap

Miscellaneous Offsite Scrap
Test Equipment/Method

Mettler Electronic Balance

Chemical Assay

Radioassay

Density Meter

Calorimeter (NDA Isotopics)

Neutron We.11 Counter (NWCC)

$\mathrm{Ge}$ (Li) Counter

Calorimeter (NDA Isotopics)

Calorimeter (NDA Isotopics)

Segmented Gamma Scan

$\mathrm{NaI}$ Counter

Segmented Gamma Scan

$\mathrm{NaI}$ Counter

Neutron Well Counter (NWCC)

Segmented Gamma Scan

$\mathrm{NaI}$ Counter

Calorimeter (NDA Isotopics)

Segmented Gamma Scan \pm Limits

5 grams*

0.5 percent

15 percent

0.2 percent

5 percent

5 percent

20 percent

10 percent

10 percent

10 percent

15 percent

10 percent

15 percent

10 percent

10 percent

25 percent

10 percent

20 percent

*Includes the weight of accumulated by-products (e.g., corrosion, moisture). The inherent weight capability of the balance should be on the order of \pm 0.1 gram. 


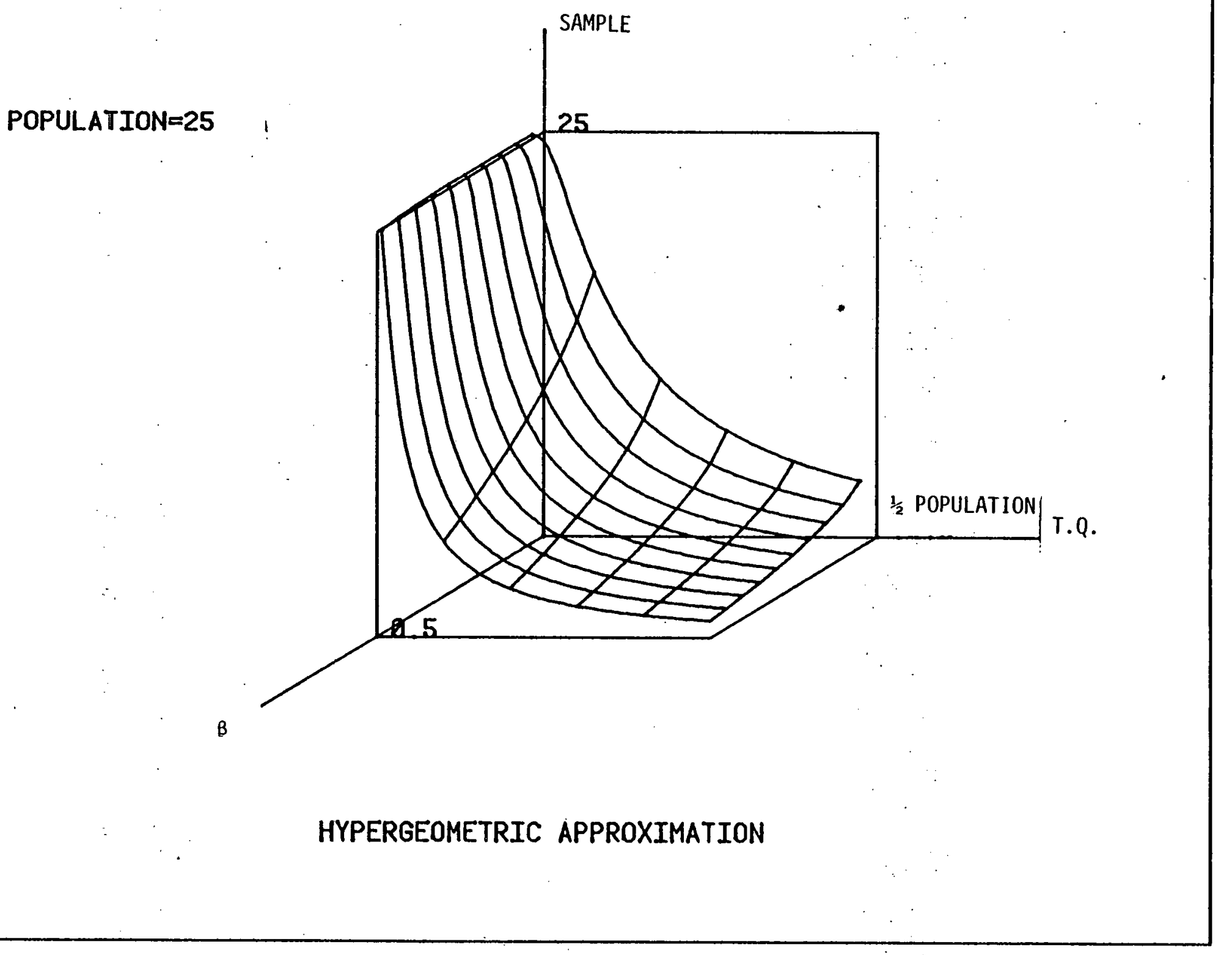




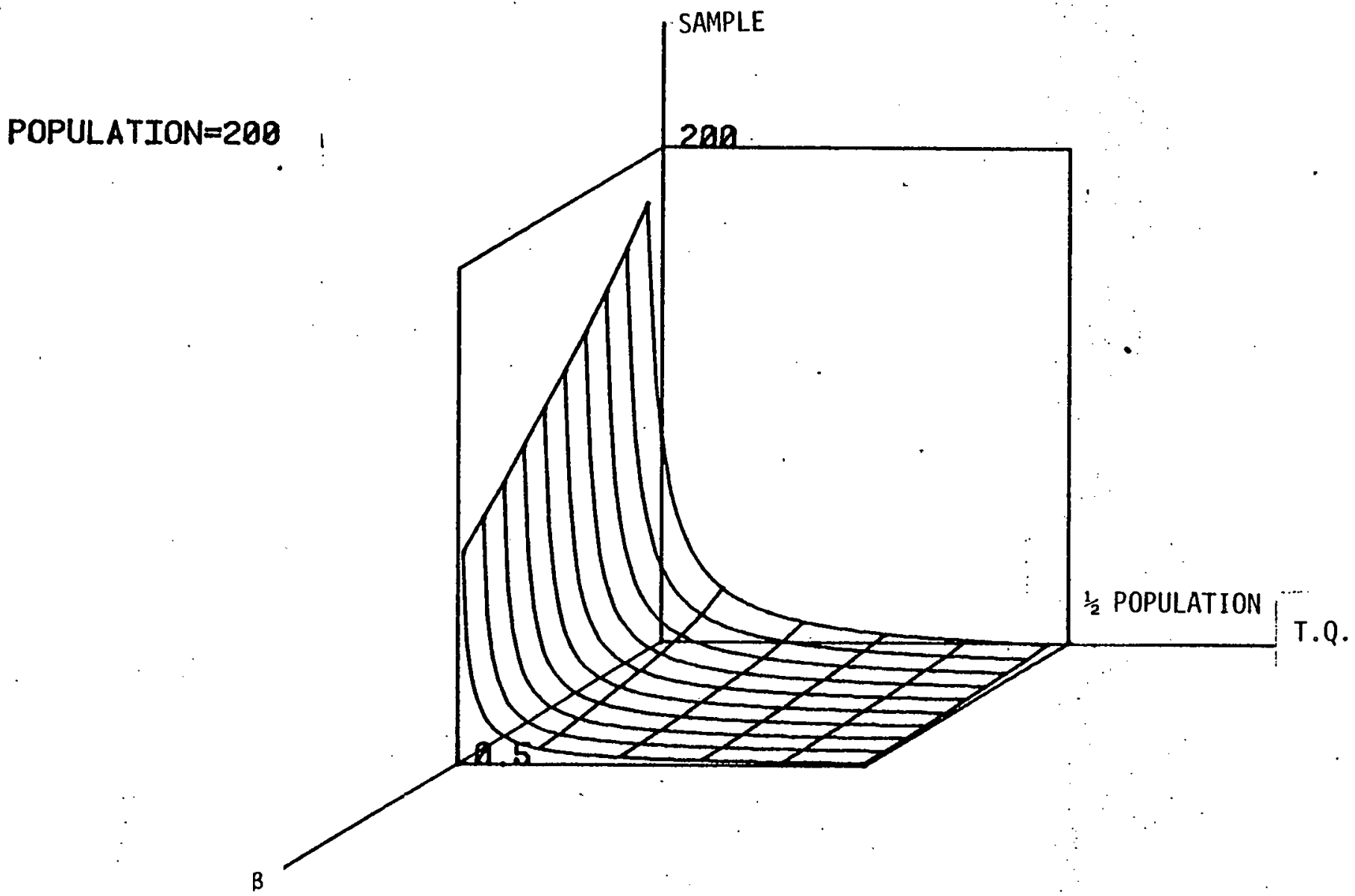

HYPERGEOMETRIC APPROXIMATION

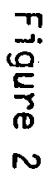




\section{APPENDIX C}


INVENTORY ACTIVITIES REPORT

Activities Report No.

Date

Item No.

\begin{tabular}{l}
$\begin{array}{l}\text { Gross weight } \\
\text { Recorded }\end{array}$ Verified \\
\hline
\end{tabular}

Remarks and Sample. Data

Signed

Principal Custodian

Signed

Inventory Personnet. 
INVENTORY DISCREPANCY SUMMARY

INDS No

ITEM NUMBER

DATE

LOCATION

SPOT LOCATION

\section{VERIFICATION REQUIRED}

BULK WEIGHT CHECK

NDA

CHEMICAL ASSAY

MEASUREMENT DATÁ

\begin{tabular}{|l|l|l|l|}
\hline & BOOK VALUES & MEASURED VALUES & DIFFERENCE \\
\cline { 2 - 4 } GROSS WEIGHT & & & \\
\hline NET WEIGHT & & & \\
\hline GRAMS PU & & & \\
\hline ISOTOPIC & & & \\
\hline
\end{tabular}

MEASUREMENT METHOD

(SGSAS)

CALORIMETER

Z-L-APU-01C

BARREL COUNTING SYSTEM

NaI COUNTER

METTLER BALANCE

NWCC

COMMENTS:

(Lab Sample No., etc.) : 


\section{INVENTORY HOLD TAG}

CAUTION: Do not move or handle without specific approval of undersigned Inventory Personner.

\section{DISPOSITION INSTRUCTIONS:}

Date

Signed

Inventory Personne]

Approved

Nuclear Materials Control 